\title{
The Role of Islamic Journalists in Fighting Hate Speech
}

\section{Yoserizal Saragih}

Universitas Islam Negeri Sumatera Utara, Indonesia

Email: yosesaragih77@gmail.com

\begin{abstract}
This paper reviews the role of journalism in preventing hate speech or hate speech that is currently rife in various media. The purpose of this paper is to increase knowledge about what is happening at this time. This paper is a descriptive analysis which aims to describe, take an inventory, and analyze the conditions being investigated in a systematic, factual and accurate manner, and then a conclusion can be drawn from the results of the study. The results of the discussion show that Islamic journalism is known as a journalist based on values and norms that adopt principles from the Qur'an and Hadith. Islamic journalism is also known as the enforcer of amar ma'ruf nahi munkar. In preventing hate speech or hate speech, there are several steps to counteract it,carry out awareness activities in the community to be wiser and smarter in using the media, cultivate tabayun attitudes, establish cooperation, and provide sanctions/fines. In addition to these steps, the role of Islamic journalism in warding off hate speech is in the form of providing education, broad knowledge, and providing direction in media wisely, wisely.ethics, manners, and full of courtesy, in using the media by adopting or applying the principles of sidhhiq, amanah, tabligh and fhatonah based on the example of the Prophet Muhammad.

Keywords: islamic journalism; hate speech
\end{abstract}

\section{Introduction}

Hate speech or hate speech is an act of communication carried out by an individual or group in the form of provocation, incitement, or insult to another individual or group in terms of various aspects such as race, color, ethnicity, gender, disability, sexual orientation, religious citizenship. and so forth. Hate speech is prohibited speech, behavior, writing, or performance because it can trigger acts of violence and prejudice either on the part of the perpetrator, statement, or victim of such action. Websitethose who use or apply hate speech are called hate sites. Hate speech can be in the form of insults, defamation, blasphemy, unpleasant actions, provocations, inciting, spreading false news. Perpetrators of hate speech can have an impact on acts of discrimination, violence, loss of life, and/or social conflict.

Throughout 2020, the Indonesian National Police (Polri) recorded: 443 casesrelated to hate speech. In addition, the National Police's Criminal Investigation Unit also stated that there were 89 content on social media that were considered to have violated hate speech. From the period of February 23 to March 11, 2021, there were 125 contents suspected of violating hate speech, of which 89 were deemed to have committed crimes of hate speech. According to Ahmad, of the 125 existing content, Twitter is dominated by the type of platform with the most content, namely 79 content, then Facebook, 32 content, Instagram 8, YouTube 5 and WhatsApp 1, so the most content is via Twitter.

The current rise of hate speech in various media is very concerning as we all know that the number of mass media users will always increase every day so that the number of hate speech in the media in the future is possible to exceed the existing number if it is not addressed immediately. Seriously both by the government and itself. 
Based on the explanation above, therefore in overcoming or preventing hate speech. There needs to be a role for Islamic journalism. As we know that Islamic journalism according to Emha Ainun Nadjib is a technology and information dissemination (in writing publishing activities) that devotes itself to Islamic religious values how and where humans, society, culture, and civilization should direct themselves. In simple terms, Islamic journalism can be interpreted as an activity of preaching through written works. The work was published in the press. Both in the form of news, features, articles, reports, headlines, and other journalistic works. Because it is intended as a message of da'wah, then the journalistic works of course contain an invitation or call about the importance of achieving success, achieving progress, doing good, and leaving humiliation. Invitations and appeals are all sourced from the aqidah of Islam, monotheism, and faith. All of that journalism has a role in conveying news and information containing virtue values to be known by the public and providing good education to the public, for example about the bad effects of hate speech itself. Based on the explanation above, the author wants to examine the extent of the role of Islamic journalism in preventing hate speech.

\section{Review of Literature}

\subsection{Understanding Islamic Journalism}

Mass media is a tool used in conveying the message from the source to the audience by using mechanical means of communication, such as newspapers, radio, television and etc. In this case, here the mass media is print media or newspapers. According to Bitter (in Muhtadi, 1999: 73), mass media is a means of transmitting information, such as newspapers, magazines, books, films, radio and television, or a combination of shapes of media forms. Meanwhile, according to Cangara (2002: 134), mass media is a tool used in the delivery of a message from the source to the audience (receiver) using a mechanical of communication such as newspapers, radio, film and television. (Saragaih, M. 2018)

Islamic journalism is a series of activities in conveying messages in the form of da'wah to the general public through media channels. The pressure is of course on the press media, both newspapers, magazines, and tabloids. Because through the press, the message of da'wah is of course delivered through written works. In summary, we can interpret Islamic journalism as an activity of preaching through written works. The work was published in the press. Both in the form of news, features, articles, reports, headlines, and other journalistic works. Because it is intended as a message of da'wah, these Islamic journalistic works must contain an invitation to do good and leave evil. The invitations are sourced from Islamic aqeedah, monotheism and faith. The definition of Islamic journalism according to several figures is as follows:

a. Emha Ainun Nadjib said that Islamic journalism is a technology and information dissemination (in writing publishing activities) that devotes itself to Islamic religious values how and where humans, society, culture, and civilization should direct themselves.

b. A. Muis said that Islamic Journalism is spreading (delivering) information to listeners, viewers, or readers about Allah's commands and prohibitions. (Quran and Hadith of the Prophet).

c. Dedy Djamaludin Malik stated that what is meant by Islamic journalism is the process of covering, processing, and disseminating various events concerning Muslims and Islamic teachings to the public. Islamic journalism is Crusade Journalism, namely journalism that fights for certain values, namely Islamic values. 
Based on some of the definitions above, it can be concluded that what is meant by Islamic journalism is a series of processes covering, processing, and disseminating various events with Islamic values by adhering to journalistic rules/norms sourced from the Qur'an and the Sunnah of the Prophet. Saw. Islamic journalism prioritizes Islamic da'wah. Those who carry out the mission of amar ma'ruf nahi munkar. The word of God in QS. Ali Imran verse 104 states, which means: "And let there be among you a group of people who enjoin the good, enjoin the good and forbid the evil, they are the lucky ones".

\subsection{Hate Speech (Hate Suggestion)}

The term hate speech is a term that has just emerged in the world of social media in the current era of globalization, which has recently become a very interesting conversation among scientists because the impact on social life is very dangerous. Since hate speech is a new term, there is no universal agreement on how to define it yet. But regardless, academics agree on how hate speech works and what its effects are. Hate speech is defined as a communication or conveying very negative ideas about a group, or group representative, where the group is defined by identity markers such as race, religion, and sexual orientation. Meanwhile, in the legal sense, hate speech is defined as a prohibited word, behavior, writing, or performance because it can trigger acts of violence and prejudice either on the part of the perpetrator of the statement or the victim of the act.

Based on the above definition, it can be concluded that hate speech is a prohibited word, behavior, writing or performance because it can trigger acts of violence and have an impact that demeans human dignity and humanity and causes prejudice on the part of the perpetrator of the statement or the victim of the statement. These actions come from various aspects such as race, skin color, gender, citizenship, and even religion.

Hate speech can simply be understood as an action that is negative in both oral and written form which is prohibited because it can trigger acts of violence and has an impact that degrades human dignity and humanity and causes bad prejudice both from the perpetrators first. again from the victims from various aspects such as race, skin color, citizenship and even religion which of course is not in line with the basic principles of Islamic teachings.

Hate speech or hate speech has several forms, namely as follows:

\section{a. Defamation}

Defamation is part of hate speech that often occurs in social life, especially in social media today. Defamation in the Criminal Code law is defined as an act of defaming a person's reputation or honor by stating something negative, both verbally and in writing.

\section{b. Insult}

Humiliation is an intense feeling that is disrespectful and expresses disdain. Contempt in psychology and other social sciences is an intense feeling of lack of respect or acknowledgment and aversion. Insults are denials that call into question moral competence and integrity. This is similar to hate, but implies a sense of superiority. A person who is contemptuous looks at an individual with contempt. People who are hated are considered unworthy. Robert C. Solomon places contempt on the same events as hatred and anger, and he argues that the difference between the three is that hatred is directed by individuals of higher status; anger is directed toward the individual's equal status, and contempt is directed toward lowering the individual's status. 


\section{c. Blasphemy}

Blasphemy in the Big Indonesian Dictionary (KBBI) is defined as a process, method or act of insulting another person in the sense of insulting, berating, degrading the person who is insulted. Meanwhile, in the KHUP, blasphemy is defined as an act committed by accusing a person or group of having committed a certain act with the intention that the accusation is spread (known to many people).

\section{d. inciting}

Incitement in the Big Indonesian Dictionary (KBBI) is defined as an act that can arouse one person's anger towards another. Meanwhile, according to R. Soesilo to incite means to encourage, invite, arouse or invite someone to do something negative. Furthermore, he said that in the word inciting, the nature of intentional and inciting is more severe than luring or persuading but it does not indicate coercion.

\section{e. Spreading Fake News}

The spread of fake news or known as hoaks is a form of hate speech that is also happening today. Hoaks can be interpreted as "deceive somebody with a hoax" (deceive a lot of people with a fake news), also means a lie, jokes and banter. It is also understood as "to deceive someone by making them believe something which has been maliciously or mischievously fabricated". While in the form of a noun, hoax is defined as "trick played on somebody for a joke" or "anything deliberately intended to deceive or trick" (anything deliberately intended to deceive others). As for the Indonesian term, hoax is an absorption word which has the same meaning as "fake news". In its use, hoax means information that is actually not true, but is made as if it is true.

Based on the forms of hate speech described above, it has a purpose or can have an impact on acts of discrimination, violence, loss of life or social conflict in the midst of social life.

\section{Research Methods}

The research method in this study is an analytical study with a descriptive qualitative approach, namely research that examines data in depth about all the complexities that exist in research and produces descriptive data in the form of written or spoken words. In this case, the writer acts as a facilitator who participates in giving critical meaning to the reality constructed by the subject under study. This research is also included in library research, namely research on news coverage in the media. Related to hate speech or hate speech. This research is also subjective-constructivist in which reality is the result of mental construction of individual social actors, so that reality is understood in various ways and is influenced by experience, context, and time. Through this research, the author examines, examines, and analyzes everything that is the subject of research to reach a conclusion.

\section{Results and Discussion}

\subsection{Hate Speech Phenomenon in Media}

After entering a new era where people begin to adapt and get used to using modern technology in their daily lives, one of which is new media. New media began to be used because conventional media had begun to be abandoned and switched to digital-based media that were computerized and connected via the internet. According to research on social media management platform HootSuite and social marketing agency We Are Social entitled "Global Digital Reports 2020" released in January 2020, almost 64 percent of Indonesia's population 
or as many as 175.4 million people are already connected to the internet network. One example of new media Internet-based is social media.From the same research source, it is stated that social media users in Indonesia have reached 160 million users or 59\% of the total population.

New media is no longer the new normal for the people of Indonesia. The data above proves that social media is a daily food for Indonesians. There are many benefits that can be obtained from being active on social media, including as a medium of communication and information, as a place for self-actualization and expression, and even to support the marketing strategy of a brand. Indeed, new media is a new innovation made to facilitate all aspects of human life, although there are some irresponsible people who use social media for negative purposes, the most common phenomena are hate speech and hoaxes.

The Head of Public Relations of the Polda Metro Jaya Kombes Pol Yusri Yunus reported, in the period from March to April 2020 there were at least 443 incoming reports relating to cases of hate speech and also false news. That means, hate speech is still a serious problem in terms of the use of social media for the people of Indonesia. the phenomenon of hate speech does not only occur during certain big moments such as the General Election. There are various motivating factors for someone to do hate speech, even for things that seem trivial. There are many things that can motivate someone to make hate speech, including personal emotional problems, disinformation or being consumed by fake news, even just because of a mere fad motive, which will end up being disastrous.

Most cases of hate speech are found on social media. The results of the investigation by the Ditreskrimsus Polda Metro Jaya found the fact that during April to May 2020 Instagram was the most widely used medium to spread hate speech, while the second rank was occupied by Facebook. Social media is not the main root cause of many new social diseases in society, one of which is hate speech.

Hate speech from irresponsible people lately can be a setback for Indonesia because hate speech eliminates mutual respect and social inequality. Hate speech is an unethical attitude, does not show nationalist and religious values, and intolerance that can encourage violence (condoning). If hate speech is not taken seriously, then this kind of attitude will become a bad asset for strengthening democracy and human rights.

The rise hate speech or hate speech can be seen on social media today. This is a challenge for both the government and Islamic journalists. The rise of this hate speech has a negative impact on establishing good relations between human beings and between religious communities that have been built so far. All religions also forbid people to hate their fellow human beings. On the contrary, religion actually teaches each of its followers to greet each other, interact, dialogue, and even work together with the spirit of loving each other, loving each other, and protecting each other.

\subsection{Steps to Prevent Hate Speech}

Hate speech or hate speech is considered a very dangerous speech because it has the opportunity to hate, violence, damage goodness in public spaces, and intimidate discrimination. Such actions undermine the dignity of human beings and their victims. There are at least two steps or ways that can be done to stem the growth and developmentHate speech or hate speech. 
First, carry out public awareness activities (media/digital literacy) so that they are wise and intelligent in regularly mediating. Because this activity is unlikely to be successful if it is only done once or twice, but it takes a long time and is consistent in various circles of society so that people become aware and media literate, that is, they can sort and choose which news or information is good and bad healthy to eat.

The second step is to cultivate the attitude of tabayun (clarification), as Allah SWT reminds in QS Hujurat: 6 "O you who believe, if a wicked person comes to you with news (hoak), check it carefully (check and recheck) so that you do not calamity befalls a people without knowing the circumstances that will cause you to regret what you did." Tabayun in the sense of seeking clarity about something until it is clear that the situation is true. Researching and selecting news, not in a hurry to decide problems, whether in terms of law, religion, public policy, socio-politics and others until the problem becomes clear.

The third step is to establish cooperation between the government, the community, and religious leaders. Cooperation can be in the form of carrying out activitiescomprehensive education related to laws and regulations related to fake news and hate speech, types, characteristics and symptoms as well as the role and function in preventing the rise of fake news and hate speech that occurs in society.

The fourth step is, give a fine, responding to the increasing prevalence of hate speech on social media, the Indonesian government has taken a firm stance with social media groups. Rudiantara, Indonesia's Minister of Communication and Information for the period 20142019, said that the government imposed fines for companies that did not remove hate speech and fake news. such as Facebook, Twitter, and Google have an obligation to create a healthy and sustainable market and reject the regime of censorship. The Indonesian government will also not hesitate to delete all content that is considered to have the potential to threaten Indonesian unity, such as radicalism and terrorism.

\subsection{Critical Race Theory In Countering Hate Speech}

School of thought critical race theory which is intended to emphasize the effect of race on a person's social status. Critical race theorycontains an activity dimension that not only regulates how people organize themselves, but also changes them for the better. Richard Delgado and Jean Stefancic in their What Is Critical Race Theory? explained that the critical race theory (CRT) movement is a group of activists and scholars interested in studying and transforming the relationship between race, racism, and power. This movement sees many emerging issues of human rights (HAM) and ethnicity, but these issues are positioned in a broad perspective, such as economic, historical, contextual, group and personal interests, and even feelings and unconsciousness.

Critical race theoryoriginally appeared in the mid-1970s. This theory was inspired by lawyers, activists, legal scholars around the world who saw the fierce debate on Human Rights (HAM) in the 1960s. Recognizing the need for new theories and strategies in rejecting forms of racism, early writers such as Derrick Bell, Alan Freeman, and Rechard Delgado (Co-author) thought how important it was to write or explain new anti-racism theories. They were soon joined by other thinkers, and the group held its first conference at the convent outside Madison, Wisconsin, in the summer of 1989.

Critical race theory experts also observe the existence of political subjectivity carried out by people or groups who have authority. If authority is made as a characteristic that must be applied, then the authoritative person or group must apply justice. The principle of justice 
in the application of law cannot be separated from the legal education system that teaches justice. Therefore, the world of education also needs to apply critical race theory to oppose and analyze ahistorical and non-contextual laws.

Based on the critical race theory, if it is related to the media, whether it is social media or not, it is still a space that has not been fully regulated in freedom of speech. However, today's media also makes it possible to be a dynamic and interactive space for hate speech. Social media platforms that are rarely monitored for abusive or discriminatory comments or language lead to content that is hurtful to people receiving hate speech. As stated by Kavanagh, et al, online interactions have a microcosm that can lead to gender, racial, sexual, and extreme violence. Furthermore, angry language that is accepted by others (whether individually or in groups) may present greater danger. Uncontrolled and negative interactions in the media have the potential to reduce inclusiveness and politeness. The negative impact of hate speech delivered through the media. Therefore, it is necessary to apply critical race theory, as explained by Mia Moody-Ramirez and Hazel James Cole. In Mia and James' analysis, critical race theory provides techniques, directions, and guidance for users of media or social media such as Twitter, Facebook, and others to communicate positively.

\subsection{Islamic Journalism in Countering Hate Speech}

As we know that journalism is the skill to write things that have just happened by paying attention with the intention that as many people know as possible and as soon as possible. According to A. Muis, stating that Islamic journalism is spreading (delivering) information to listeners, viewers or readers about Allah's commands and prohibitions. (Quran and Hadith of the Prophet).

In preventing hate speech or hate speech, Islamic journalism has an important role in this regard, because if there are things that are prohibited in religion or Islam such as slanderous news, lies, pitting, provocation, gender violence, racial, sexual, extreme, verbal abuse. abuse or discrimination, and so on. It is not true in Islam. Thus, Islamic Journalism is a solution to current problems such as hate speech in the media which is often not directed. Lots of slanderous news that is not in accordance with the truth published by well-known media. Journalistic media often lose their independent character when they come into contact with money and power. Many media are also unprofessional by not carrying out the tabayyun process for news. In fact, it could be that the impact of the news published is quite significant on people's lives. The media need to be held responsible if news that is not true due to negligence or other things is published so that it disturbs the public. These are some examples of things in journalism that are not in accordance with Islamic principles and values. There are many other things that actually violate Islamic rules. In fact, most of the journalists are Muslims who should know the limits of what is lawful in their religion.

In principle, Islamic journalism has the characteristics as exemplified by the Prophet Muhammad: First, Siddiq Al-shidq refers to the notion of being honest in communicating, both verbally and in writing. In the context of journalism, including in loading information, whether on social media or not, so that hate speech does not occur. This shiddiq principle is very important to be applied in preventing hate speech and hate speech. Because shiddiq is informing something that is true and defending and upholding that truth. The standard of truth is of course conformity with Islamic teachings (Qur'an and As-Sunnah). Second, amanah means trustworthy, trustworthy, so it is not permissible to lie, manipulate, manipulate or distort facts. Third, tabligh means conveying, that is, informing the truth, not distorting the truth. Four, fathonah means intelligent and broad-minded. 
These principles can be educational in preventing hate speech or hate speech. In addition to applying the principles above, providing direction in every existing media on the careful use of digital media and spreading ethics in using the media. Then cultivate the attitude of tabayyun, this principle can be used in counteracting hate speech, in this way and accompanied by giving about the dangers of hate speech and the impact of hate speech itself.

In addition, Islamic journalism continues to apply the shiddiq principle in informing what is true and defending and upholding the truth. In preventing hate speech, every information provided is based on shiddiq, because by educating the public with this principle, it can make people aware of the dangers of hate speech. And actions in hate speech are prohibited in Islam and less ethical in socializing. Then the trust or trustworthiness in providing information to the public is very important principle. Because this can be done in preventing hate speech. Educating the public to apply the principle of trust in any available information as well as providing extensive knowledge about this principle is likely to reduce hate speech.

\section{Conclusion}

Islamic journalism is a series of processes covering, processing, and disseminating various events containing Islamic values by complying with journalistic rules/norms that are sourced from the Qur'an and Sunnah. Islamic journalism is known for its emphasis on Islamic da'wah, which carries out the mission of enjoining ma'ruf nahi munkar. In terms of preventing hate speech or hate speech, Islamic journalism has a very important role in this problem. The steps taken to counteract the hate speech found in this study are:carry out awareness activities in the community to be wiser and smarter in using the media, cultivate tabayun attitudes, establish cooperation, and provide sanctions/fines. In addition to these steps, the role of Islamic journalism in countering hate speech is in the form of providing education, broad knowledge, and providing direction in media with the principles of sidhhiq, amanah, tabligh and fhatonah based on the example of the Prophet Muhammad.

\section{References}

Andi Abdul Muis. (2001). Komunikasi Islami, Bandung: PT Remaja Rosdakarya.

Annisa Ulfa Hariyanti. (2016). Perspektif Hukum Islam tentang Penerapan Undang-undang ITE No. 19 Tahun tentang Hate Speech, skripsi.

Anton Ramdan. (2015). Jurnalistik Islam, Jakarta: Shahara Digital Publishing.

Arwendria, A. and Oktavia, A. (2020). Upaya Pemerintah Indonesia Mengendalikan Berita Palsu. World's Most Literate Nations, diakses di http://www.ccsu.edu/wmln/rank.html Kemp. Digital 2020: Indonesia. Datareportal, diakses pada: 26 September 2021.

Ayuningtyas Saptarini dan Dina Tsalist Wildana. (2017). Eksistensi Penganut Aliran Kepercayaan dan Kompleksitas Hak Kebebasan Beragama di Indonesia, Yogyakarta: LKiS \& CHRM2 Universitas Jember.

Cherian George. (2017). Pelintiran Kebencian; Rekayasa Ketersinggungan Agama dan Ancamannya bagi Demokrasi, Jakarta: Pusad.

Dendy Sugono. (2011). Kamus Besar Bahasa September 2021. Indonesia, Jakarta: Gramedia Pustaka Utama.

Direktorat Tindak Pidana Siber Bareskrim Polri, Diketahui Dari Patroli Virtual Police, diakses pada: 25 September 2021.

Eni Amaliah. (2021). Jurnalistik Islam Di Era Media Sosial, Jurnal Komunikasi, diakses pada: 26 September. 
Haris Quds. (2021). Critical Race Theory dan Perkembangannya di Amerika, https://harisquds.medium.com/critical-race-theory-dan-perkembangannya-diamerika-2199d7d2315a, diakses pada: 26 September.

Hate Speeches on Social Media Concern President Jokowi, http://bit.ly/hatespeeches, diakses pada: 26 September 2021.

Hikmat, Mahi M. (2014). Metode Penelitian dalam Perspektif Ilmu Komunikasi dan Sastra, Yogyakarta: Graha Ilmu.

Hoax. (2021). Wiktionary, https://en.wiktionary.org/wiki/hoax\#English, diakses pada: 26 September 2021. https://id.wikipedia.org/wiki/Ucapan_kebencian, diakses pada: 25 September.

Husain Junus \& Aripin Banasuru. (1996). Seputar Jurnalistik, Solo: CV Aneka.

Irwan. (2018). Hate Speech di Indonesia: Bahaya dan Solusi, Jurnal Dakwah dan Pengembangan Sosial Kemanusiaan Vol. 9, No. 1 Jurnal Tahun.

Jeremy Waldron. (2000). the Harm in Hate Speech, Cambridge: Harvard University Press.

John M Echols \& Hassan Shadily. (2005). An English-Indonesia Dictionary, Jakarta: PT Gramedia Pustaka Utama.

Kepala Kepolisian Negara Republik Indonesia, Surat Edaran Kapolri Nomor: SE/06/X/2015 tentang Penanganan Ujaran Kebencian (Hate Speech).

Kriyantono, Rachmat. (2010). Teknik Praktis Riset Komunikasi, Jakarta: Kencana Prenada Media Group.

Nawawi, Hadari. (1991). Metodologi Penelitian Bidang Sosial, Yogyakarta: Gajahmada Pers.

Oxford University. (2011). Oxford: Learner's Pocket Dictionary, Oxford: Oxford University Press.

Peter Salim. (1996). the Contemporary English-Indonesia Dictionary, Jakarta: Modern English Press: Jakarta.

R. Soesilo. (1991). Kitab Undang-Undang hukum Pidana serta Komentar Lengkap Pasal demi Pasal, Bogor: Politea.

Richard Delgado and Jean Stefancic. (2001). Critical Race Theory: An Introduction, New York and London: New York University Press.

Saragaih, M. (2018). Some Characteristics of Islamic Journalism Based on Al Quran. Budapest International Research and Critics Institute-Journal (BIRCI-Journal). 01-10.

Suf Kasman. (2004).Jurnalisme Universal, Jakarta: Teraju. Jurnal \& Skripsi

Yudha Prawira. (2016). Upaya Kepolisian dalam Menanggulangi Kejahatan Ujaran Kebencian (Hate Speech) Berdasarkan Surat Edaran kapolri No SE/06/X/2016, Skripsi, Lampung: Universitas Lampung. 